\title{
The Emergence of Orthodontics as a Specialty in Britain: The Role of the British Society for the Study of Orthodontics
}

\author{
GEOFFREY STUART TAYLOR and MALCOLM NICOLSON*
}

By the end of the twentieth century, orthodontic treatment, the correction of irregularities of the teeth and jaws, had become widely available in Britain, both under the National Health Service and privately. However, the statutory recognition of orthodontics, and the other dental specialties, is very recent. It was only in 1999, following the recommendations of the Calman Report, that the Dentists Register incorporated, for the first time, lists of the recognized specialties within dentistry. ${ }^{1}$ But British orthodontics had acquired some of the trappings of specialization many years before it achieved this legal status. In 1907, British orthodontists set up their own learned society and began to publish a dedicated journal. Through the early decades of the century, orthodontic departments were gradually established within dental teaching hospitals. The publication of the 1999 Dentists Register represented, moreover, the culmination of a long-term trend towards the correction of irregular dentition being undertaken by specialist orthodontists rather than by dentists in general practice. The present paper aims to follow aspects of the development of a distinctive professional identity among British orthodontists from the late nineteenth century onwards, with particular reference to the role played by the British Society for the Study of Orthodontics (BSSO). ${ }^{2}$

Orthodontics is significant in the history of dentistry since it was the first division of dentistry to approach specialty status. ${ }^{3}$ Moreover, its patterns of training provided a template that was followed by the other dental specialties as they differentiated. ${ }^{4}$ The growth and background of the various dental specialties has, however, received relatively little attention in the historical literature. The history of British orthodontics, in particular, has largely remained in the hands of its practitioners. Useful as the accounts of Barry Leighton, Reginald Howard, James Moss and Jeffery Rose undoubtedly are, they have reflected

(C) Geoffrey Stuart Taylor and Malcolm Nicolson 2007

*Geoffrey Stuart Taylor, DDS, FDS, 47 Millig Street, Helensburgh, Argyll and Bute, G84 9PN, UK; e-mail: stuart@gs-taylor.co.uk.

Malcolm Nicolson, BSc, PhD, Centre for the History of Medicine, Department of Economic and Social History, Lilybank House, University of Glasgow, G12 8RT, UK; e-mail: wellmn@ arts.gla.ac.uk. (Correspondence to the first author.)

Both authors wish to acknowledge the generous support of the Wellcome Trust.

${ }^{1} \mathrm{~K}$ Calman, Hospital doctors: training for the future, London, HMSO, 1993; Dentists
Register, London, General Dental Council, 1999.

${ }^{2}$ This paper is based on a larger study, G S Taylor, 'Review of the Transactions of the British Society for the Study of Orthodontics, 1907-1971', DDS Thesis, University of Glasgow, 2004.

${ }^{3}$ We are using "division" in the same sense as G Weisz, Divide and conquer: a comparative history of medical specialization, Oxford University Press, 2006, p. 191.

${ }^{4}$ For an example of orthodontic training leading the way for other specialities, see F P G M van der Linden, 'Three years postgraduate programme in orthodontics: the final report of the Erasmus Project', Eur. J. Orthod., 1992, 14: 85-94. 


\section{Geoffrey Stuart Taylor and Malcolm Nicolson}

a professional, and indeed a commemorative, agenda. ${ }^{5}$ It is hoped that the present paper, written jointly by an orthodontist and a medical historian, will help to open up an interesting and neglected area.

Unlike its dental equivalent, the process of specialization in medicine has generated a considerable amount of secondary literature. ${ }^{6}$ Rosemary Stevens, in her pioneering and authoritative study of the growth of specialization in British medicine, presented the development of specialties as inevitable, and desirable, given the great expansion of medical knowledge in the twentieth century. ${ }^{7}$ Later, however, Glenn Gritzer and Arnold Arluke effectively challenged the view that medical specialization was the necessary result of new technologies or was a natural consequence of the inexorable growth of knowledge. ${ }^{8}$ In his account of the development of orthopaedics as a specialty in Britain, Roger Cooter has likewise pointed out the inadequacy of teleological models of the process of medical specialization. ${ }^{9}$ Far from being inevitable, or even necessarily aspired to, moves towards specialization have always been contingent upon factors of professional identity and authority, and national and cultural context. This is also the compelling conclusion of George Weisz's recent comprehensive comparative study of the growth of specialization in France, Germany, Britain and the USA. Weisz acknowledges the force of Stevens' argument that, within the institutional framework of the health services of the advanced industrial nations, there were many factors encouraging medical specialization, but he notes that none of these were sufficiently compelling to determine the extent or character of the process. ${ }^{10}$

To Gritzer and Arluke, the division of medical labour was a consequence of the intensity of competition in the market for medical services. They drew their conclusions from a study of the development of the specialty of rehabilitation medicine in the twentiethcentury United States. Lindsay Granshaw's analysis was not dissimilar, although her subject matter was British surgery in the nineteenth century. ${ }^{11}$ However, as Weisz and Cooter have both argued, the market model may not be appropriate to every instance of

${ }^{5}$ B C Leighton, 'The British Society for the Study of Orthodontics', Br. dent. J., 1968, 124: 425-8, was published to mark the golden jubilee of the BSSO. The centenary of the British Dental Association in 1981 occasioned B C Leighton and R D Howard, 'Orthodontics - the last hundred years', Br. dent. J., 1981, 151: 14-19, and the fiftieth anniversary of the NHS was marked by B C Leighton and J P Moss, 'Orthodontics in the National Health Service', Br. dent. J., 1998, 185: 24-6; see also J S Rose, et al., A history of the British orthodontic societies (1907-1994), London, British Orthodontic Society, 2002; and S Gelbier, 'Britain's first community orthodontic scheme: for the children of Heston and Isleworth', Med. Hist., 1985, 29: 414-32. Weinberger's very detailed study of the early years of the specialty in the United States contains a number of British references, B W Weinberger, Orthodontics: an historical review of its origin and evolution, St Louis, C V Mosby, 1926.

\footnotetext{
${ }^{6}$ For an authoritative survey, see Weisz, op. cit., note 3 above, pp. xii-xv.

${ }^{7} \mathrm{R}$ Stevens, Medical practice in modern England: the impact of specialization and state medicine, New Haven, Yale University Press, 1966.

${ }^{8} \mathrm{G}$ Gritzer and A Arluke, The making of rehabilitation: a political economy of medical specialization, 1890-1980, Berkeley, University of California Press, 1985; see also G Larkin, Occupational monopoly and modern medicine, London, Tavistock, 1983.

${ }^{9} \mathrm{R}$ Cooter, Surgery and society in peace and war: orthopaedics and the organization of modern medicine, 1880-1948, Basingstoke, Macmillan, 1993.

${ }^{10}$ Weisz, op. cit., note 3 above, pp. xviii-xxii.

${ }^{11}$ L Granshaw, "Fame and fortune by means of bricks and mortar": the medical profession and specialist hospitals in Britain, 1800-1948', in L Granshaw and R Porter (eds), The hospital in history, London, Routledge, 1989,
} pp. 199-220. 


\section{The Emergence of Orthodontics as a Specialty in Britain}

medical specialization. ${ }^{12}$ In the present study we have found little evidence that orthodontists advanced the cause of specialization to secure a direct commercial advantage over other dental practitioners, or that the founding of the first British orthodontic society was an occupational strategy designed to secure superior remuneration and status, as Parry and Parry might suggest. ${ }^{13}$ This is not to say, of course, that orthodontists did not benefit from the professional and political campaigns that secured a legal monopoly for qualified dentists. ${ }^{14}$ Indeed, it is unlikely that the BSSO would have been formed if the status of dentistry had not greatly improved in late nineteenth- and early twentieth-century Britain. Nor is it to argue that orthodontists did not have professional interests. Indeed, it was the failure of the BSSO to represent those interests that finally brought about its demise.

Following Weisz, we would also argue that the presence of a distinctive body of scientific and clinical knowledge, while not necessarily triggering a trend towards specialization, cannot be regarded as irrelevant to the specialization process. ${ }^{15}$ The present study explores the manner in which British orthodontists gradually acquired and cultivated a sense of their own distinctiveness from other dental practitioners. We argue that this was partly owing to their development and elaboration of orthodontic knowledge and technique. It was also partly due to an awareness of how far specialization in orthodontic practice and training had advanced in the United States. In other words, we will emphasize the role of material and conceptual culture in the specialization process.

To accord a secondary importance, in this instance, to market forces is not, as we have already indicated, to deny that issues of professional identity were central to the process of specialization in orthodontics. As Luke Davidson has emphasized, in Britain tendencies towards medical specialization had constantly to be balanced against the prevailing generalist character of British medicine. ${ }^{16}$ Also, as David Cantor has shown, the meaning of specialization may vary according to context. ${ }^{17}$ Cultivating the role of the specialist might, on occasion, provoke accusations of undue narrowness of outlook, or worse, allegations of quackery, but it might also, under different circumstances, constitute an assertion of distinctive technical and cognitive competence. By studying the proceedings of the $\mathrm{BSSO}$, the present paper follows the process of specialization in orthodontics through the study of the significance of the term in the discourse of orthodontists themselves.

\section{Orthodontics in Britain}

Several eighteenth-century British authors, notably John Hunter, discussed the problems associated with irregular dentition. ${ }^{18}$ However, the first English textbook to be devoted to

\footnotetext{
${ }^{12}$ Weisz, op. cit., note 3 above, pp. 42-3; $\mathrm{R}$ Cooter, review of Glenn Gritzer and Arnold Arluke, The making of rehabilitation: a political economy of medical specialization, 1890-1990, Med. Hist., 1986, 30: 479. Weisz's point, in this respect, relates only to Britain.

${ }^{13} \mathrm{~N}$ Parry and J Parry, The rise of the medical profession, London, Croom Helm, 1976.

${ }^{14} \mathrm{E}$ G Forbes, 'The professionalization of dentistry in the United Kingdom', Med. Hist., 1985, 29: 169-81.
}

\footnotetext{
${ }^{15}$ Weisz, op. cit., note 3 above, p. xxi.

${ }^{16}$ L Davidson, "Identities ascertained": British ophthalmology in the first half of the nineteenth century', Soc. Hist. Med., 1996, 9: 313-33.

${ }^{17} \mathrm{D}$ Cantor, 'The contradictions of specialization: rheumatism and the decline of the spa in inter-war Britain', in R Porter (ed.), The medical history of waters and spas, London, Wellcome Institute, pp. 127-44.

${ }^{18} \mathrm{~J}$ Hunter, A practical treatise on diseases of the teeth intended as a supplement to the natural
} 


\section{Geoffrey Stuart Taylor and Malcolm Nicolson}

the subject matter of what would later be termed orthodontics appeared in 1803. Joseph Fox's Natural history of the human teeth, subtitled, describing the proper mode of treatment to prevent irregularities of the teeth, detailed several practical methods for altering the position and orientation of teeth in the mouth. ${ }^{19}$ In 1829 Thomas Bell published The anatomy, physiology and diseases of the teeth, in which he also discussed orthodontic problems and techniques. ${ }^{20}$ Five years later, William Imrie, in his interestingly titled Parents' dental guide, attributed irregularity of teeth to "intemperance of various kinds, combined with artificial modes of living". ${ }^{21}$ James Robinson published The surgical, mechanical, and medical treatment of teeth in 1846, which contained his ideas on aetiology and treatment. ${ }^{22}$ It is clear, from these texts, that procedures aimed at straightening the teeth were already part of the general dental surgeon's repertoire by the first half of the nineteenth century.

In 1829, Bell, lecturer at Guy's Hospital on the anatomy and diseases of the teeth, expressed misgivings regarding the quality of much of the treatment on offer to "regulation cases", as they were then termed:

There is not a subject connected with that branch of practice, of which the present work professes to treat, which has given rise to such gross charlatanism, or to so much gratuitous cruelty, as that which regards the treatment or prevention of irregularity in the permanent teeth. ${ }^{23}$

Concerns of this sort were, however, not uncommonly voiced with regard to many aspects of dentistry at this time. The practice of dentistry was still unregulated; there were no recognized training programmes or prerequisite educational requirements. The betterqualified practitioners, such as Bell, MRCS (later FRCS) and FRS, found much to complain about.

In Britain, for much of the nineteenth century, dental work was undertaken by three dissimilar groups of practitioners. The members of the first group, small in number but perhaps the most influential, had recognized medical qualifications, which they had augmented by a short period of training in dentistry. These men were based predominantly in London and some of the larger provincial cities; most of them, like Bell, held hospital or dispensary appointments at some stage in their careers. The authors whose publications have been discussed above are representative of this group.

The second group had acquired their dental skills primarily by way of an apprenticeship, of variable length and effectiveness, to an established dental practitioner. The numbers of this category of practitioner grew as the century progressed. The third group, perhaps the largest, and the most readily available to the general population, had little formal training and often combined their dental work with some other occupation, such as druggist or barber. $^{24}$

history of those parts, London, Johnston 1778.

${ }^{19} \mathrm{~J}$ Fox, Natural history of the human teeth, ... describing the proper mode of treatment to prevent irregularities of the teeth, London, Thomas Cox, 1803.

${ }^{20} \mathrm{~T}$ Bell, The anatomy, physiology and diseases of the teeth, London, Highley, 1829.

${ }^{21} \mathrm{~W}$ Imrie, Parents' dental guide: a treatise on the diseases of the teeth and gums, London, Churchill,
1834 , p. 33 , also cited inWeinberger, op. cit., note 5 above, p. 215.

${ }^{22} \mathrm{~J}$ Robinson, The surgical, mechanical, and medical treatment of the teeth: including dental mechanics, London, Webster, 1846.

${ }^{23}$ Bell, op. cit., note 20 above, pp. 82-3.

${ }^{24} \mathrm{C}$ Hillam (ed.), The roots of dentistry, London, British Dental Association, 1990, pp. $38-45$. 


\section{The Emergence of Orthodontics as a Specialty in Britain}

The forms of treatment offered by the different groups varied. Those who were medically qualified tending towards a surgical orientation, which encompassed the whole of the buccal cavity. The second group, those who had followed the apprenticeship route, generally adopted a more mechanical approach, with an emphasis on the filling of teeth and the fitting of prostheses. They would also perform extractions. The activities of this group most closely resembled the general dental practitioners of today. The services offered by the third group were more basic, chiefly involving the extraction of painful teeth.

The Medical Act of 1858 regulated the practice of medicine, laying down statutory educational requirements and establishing a Medical Register, which was administered by the General Medical Council (GMC). The Medical Act also empowered the Royal College of Surgeons of England to award, by examination, a Licence in Dental Surgery. The first diet of this examination took place in 1860. Realizing the benefits of the Medical Act, the leading dentists, many of whom were, as noted above, medically qualified, urged that similar provisions be made for dentistry. Sir John Tomes, MRCS (later FRCS) and FRS, was prominent in these campaigns.

While Tomes and his peers were campaigning for the establishment of a regulated system of dental qualification and registration, they were also active in expanding dentistry's institutional base. The Dental Hospital of London was founded in 1858, and its associated London School of Dental Surgery in the following year. ${ }^{25}$ The rival Metropolitan School of Dental Surgery (which later became the National Dental Hospital) was also established in 1858, just before the Royal College of Surgeons of England began examining for the newly created LDS. ${ }^{26}$ The Edinburgh Dental Dispensary, run and staffed by surgeons, was founded in $1860 .{ }^{27}$ In 1863 , the Odontological Society of Great Britain was formed, from the merger of two older, rival dental societies, under the leadership of Tomes and Samuel Cartwright, the professor of dental surgery at King's College Hospital.

A long political campaign achieved success in 1878, with the passage of the first Dentists Act, which extended the remit of the GMC to allow some regulation of dental practice. The Act also empowered the surgical Colleges of Edinburgh and Dublin and the Faculty of Physicians and Surgeons of Glasgow to offer examinations in dentistry similar to that of the London College. While it would be more than a further forty years before all unregulated practice was finally controlled, the passing of the 1878 Act was an indication of the growing professional and social status of dentistry. ${ }^{28}$

Generalism had been the dominant ideology of nineteenth-century British medicine. In 1881, Sir John Russell Reynolds, later president of the Royal College of Physicians and the British Medical Association, maintained that "specialism" denoted "miserable

\footnotetext{
${ }^{25}$ See E G Smith and B D Cottell, A history of the Royal Dental Hospital of London and School of Dental Surgery 1858-1985, London, Athlone, 1997.

${ }^{26} \mathrm{~J}$ A Donaldson, The National Dental Hospital 1858-1915, London, British Dental Association, 1992.
}

\footnotetext{
${ }^{27}$ J Menzies Campbell, Dentistry then and now, Glasgow, privately printed, 1981, p. 167; W Guy, 'The story of the Edinburgh Dental Hospital and School', Dental Magazine and Oral Topics, 1936, 53: 27-39,142-53, 240-54.

${ }^{28}$ Guy, op. cit., note 27 above, p. 28; also Menzies Campbell, op. cit., note 27 above, p. 304.
} 


\section{Geoffrey Stuart Taylor and Malcolm Nicolson}

retrogression instead of evolution: [and] the survival not of the fittest, but of the charlatan and the quack". ${ }^{29}$ As we shall see, similar views continued to be articulated by many, well into the twentieth century. However, as David Innes Williams has pointed out, the formation of the Royal Society of Medicine (RSM) in 1907 signalled a new, more positive, attitude to specialization within medicine itself. The RSM was organized into thirteen sections, rather than the traditional tripartite division of physic, surgery and obstetrics. The Odontological Society was incorporated into the RSM as one of its original constituent sections, which represented an acceptance of the place of dentistry within the medical establishment. $^{30}$

By this time, specialization had had little impact within general dentistry. However, many of the leading dentists, mostly members of the first group described above, regarded dentistry as a division within medicine and themselves as medical practitioners who had taken a special interest in dentistry. The meaning of specialism varied, in other words, according to whether one regarded medicine or dentistry as the parent, generalist discipline.

Meanwhile, the demand for treatment to correct irregularities of the teeth and jaws continued to grow. ${ }^{31}$ Earlier in the nineteenth century patients undergoing treatment to straighten their teeth were described as "regulation cases"; a reference to the fact that the aim of treatment was to correct what were called "irregularities of the teeth". By the middle of the century, however, the term "malocclusion" was coming into common use. This change of vocabulary signalled a shift of emphasis away from a narrow focus just on the position of the front teeth, towards the consideration of both the relationship of teeth to each other, and to the teeth in the opposing jaw. The clinical practice of correcting malocclusion then became known as "orthodontia". ${ }^{32}$ Later the term "orthodontics" was preferred. $^{33}$

As the nineteenth century proceeded, the materials available to practitioners of "orthodontia" were improved and new methods were widely adopted. William Imrie, for example, made significant changes to orthodontic technique in the $1830 \mathrm{~s} .{ }^{34} \mathrm{He}$ used plaster models of the dentition, made caps for teeth, which were soldered to arches to reinforce anchorage, and introduced gold bite plates to be used over the palate. A treatise by Charles Gaine, of Bath, published in 1856, is interesting in that it draws on the records of successfully treated cases. ${ }^{35}$ Gaine is credited with the introduction, simultaneously with W H Dwinelle in the USA, of the jackscrew into orthodontics, an innovation that was to

\footnotetext{
${ }^{29}$ J R Reynolds, 'Specialism in medicine: address to the Medical Society, University College London, October 1881', in idem, Essays and addresses, London, Macmillan, 1896, pp. 194-207, p. 198. Emphasis in original, punctuation has been modified for clarity.

${ }^{30}$ D Innes Williams, 'RSM 1907: the acceptance of specialization', J. Roy. Soc. Med., 2000, 93: 642-5.

${ }^{31}$ One of the reasons for the development of a specialty of orthodontics must have been that there was a greater demand for the services of orthodontists. The role of the patient in seeking cosmetic improvement, an increased concern with the appearance of the mouth and so forth, in the history of the subject has been little
}

investigated, however, and, while fascinating, is not discussed in this paper.

${ }^{32} \mathrm{C}$ A Harris, A dictionary of dental science, biography, bibliography and medical terminology, Philadelphia, Lindsay \& Blakiston, 1849

${ }^{33}$ For the change of name, see G S Taylor, 'Orthodontics v. orthodontia', J. Orthodontics, 2003, 30: $175-7$.

${ }^{34}$ Imrie, op. cit., note 21 above, esp. ch. 5 , also cited in Weinberger, op. cit., note 5 above, p. 218.

${ }^{35} \mathrm{C}$ Gaine, On certain irregularities of the teeth with cases illustrative of a novel method of successful treatment, Bath, C W Oliver, 1858. 


\section{The Emergence of Orthodontics as a Specialty in Britain}

have a great impact on the ability to move individual teeth and to expand the distance between rows of teeth. Gaine also recognized the need to maintain the teeth in their corrected positions for a period of time after tooth movement had been completed. Like Bell, he urged that orthodontic treatment be undertaken only by those competent to do so. The development of a technology specific to the correction of irregular dentition gave its practitioners a stronger claim to a distinctive skill, as well as a greater sense of professional identity. ${ }^{36}$

Vulcanite was patented in 1844 by Charles Goodyear and rapidly found application in dentistry, providing a distinct improvement in the production of both dentures and regulation plates. In a series of papers published in the 1870s, F H Balkwill described a further refinement in the use of the material, whereby the vulcanite was applied directly to the working plaster model of the teeth. ${ }^{37}$ This avoided the need to construct a model of the appliance in wax. The new technique significantly improved accuracy, and drastically reduced workshop time. Balkwill's papers demonstrate that British dentists were actively innovating in the field of orthodontics in the second half of the nineteenth century. Although his appliances may seem crude by modern-day standards, they demonstrated many ingenious features, and appear to have been effective. Many of the nuances of tooth movement were, evidently, well appreciated at this time. Moreover, the fact that Balkwill worked in Plymouth indicates that the provision of orthodontic treatment was not limited to the metropolis.

Following the 1878 Dentists Act, the newly created dental schools incorporated some teaching of orthodontics into their curricula. The 1882 "Student Supplement" of the British Journal of Dental Science listed lectures on irregularities of teeth as part of the dental surgery and pathology courses offered at both the National Dental Hospital and the Dental Hospital of London. ${ }^{38}$ Orthodontic subject matter appeared both in the major general textbooks and in more specific volumes. Of the latter, James Oakley Coles' On deformities of the mouth, congenital and acquired, and their mechanical treatment, first published in 1868, ${ }^{39}$ and J F Colyer's Notes on the treatment of irregularities in position of the teeth, are notable. ${ }^{40}$ Articles on orthodontics began to appear regularly in the dental periodical literature. The first formal course of lectures on "what was later known as orthodontics" was delivered by John Henry Badcock, dental surgeon to Guy's Hospital, shortly after his appointment in $1900 .^{41}$

J A Donaldson, in his history of the National Dental Hospital, accurately describes the situation existing in most dental schools around the turn of the century:

There was an increasing interest in orthodontics, partly as a result of lectures and writings by practitioners who had studied in the United States of America, and partly because it was a field soon to be included in the requirements of examining bodies. By 1902, this led to the adoption by the

\footnotetext{
${ }^{36}$ Weisz, op. cit., note 3 above, makes a similar point regarding the differentiation of ophthalmology, pp. 131 and 210-11.

${ }^{37} \mathrm{~F}$ H Balkwill, 'On regulation plates', Br. J. Dent. Sci., 1876, 19: 9-13, 70-73, 128-32, 174-7.

38 'Student Supplement', Br. J. Dent Sci., 1882, 25: $901-27$
}

\footnotetext{
${ }^{39}$ James Oakley Coles, On deformities of the mouth, congenital and acquired, and their mechanical treatment, London, Churchill, 1870.

${ }^{40} \mathrm{~J}$ F Colyer, Notes on the treatment of irregularities in position of the teeth, London, Dental Manufacturing Co., 1900.

${ }^{41}$ J H Badcock, 'Autobiography of John Henry Badcock', Br. dent. J., 1954, 96: 25-30.
} 


\section{Geoffrey Stuart Taylor and Malcolm Nicolson}

National Dental Hospital of "rules for regulation cases" ... and the fitting up of a room on the first floor for their treatment, but no teacher was appointed at this time. The treatment of each case was undertaken by a student under the supervision of the Dental Surgeon of the day. ${ }^{42}$

In other words, orthodontic theory and practice were still being taught as integrated aspects of general dentistry.

Nevertheless, from 1903 onwards, the staff lists of the Manchester Dental Hospital contain the names of a number of orthodontic demonstrators or tutors and, in 1909, mention is made for the first time of the existence of a separate Orthodontic Department. In the same year, George G Campion was appointed as lecturer in orthodontics to the Victoria University, Manchester. ${ }^{43}$ By 1905 a "Regulation Room" had been established in the Royal Dental Hospital, staffed by the "Regulation Room House Surgeon". 44 By the beginning of the next decade, a number of other hospitals had followed suit. However, no formal postgraduate courses in orthodontics existed and many British dentists interested in the subject went to the United States for advanced training. ${ }^{45}$ For example, in the first decade of the twentieth century, Harold Chapman, Hubert Visick, A C Lockett, David Fyfe and Ernest Sheldon Friel all attended the school run by the pre-eminent American orthodontist, Edward Angle, originally in St Louis. ${ }^{46}$ By this time there were several full-time orthodontists in North America, most notably Angle himself, who had entered dedicated practice in 1892, but, as yet, none at all in Britain. ${ }^{47}$ A pupil of Angle, Friel, in Dublin, set up the first such practice in the British Isles in $1909 .^{48}$

Orthodontics appears to have caught the dental imagination in the early years of the twentieth century. It is revealing, for instance, that the American, the British, the German, and the European orthodontic societies were all founded within ten years of each other. Some authorities, notably the leading historian of orthodontics B W Weinberger, have attributed this widespread surge of interest to the impact of Angle's writings. ${ }^{49}$ There is certainly no doubt that, when compared to the situation in Britain, the teaching and the practice of orthodontics in North America were more established, better organized and more sophisticated, or that Angle was a dominant (if controversial) figure in American orthodontics. It is telling, for instance, that Angle's pupils from the British Isles, notably Chapman, Friel and Visick, came to occupy leading positions within British orthodontics. Prolific authors of research papers, all three were founder members of the BSSO, Chapman and Friel serving as president. ${ }^{50}$

Angle's teaching was predicated upon the assumption that orthodontics should be a specialty wholly independent of general dentistry. ${ }^{51}$ Part of the rationale for a specialist

\footnotetext{
${ }^{42}$ Donaldson, op. cit., note 26 above, p. 88 .

${ }^{43}$ Educational Supplement, Br. dent. J., 1903, 24: xxxii; Educational Supplement, Br. dent. J., 1909, 30: 941 .

${ }^{44}$ Smith and Cottell, op. cit., note 25 above, p. 88 .

${ }^{45}$ Weisz notes that dentistry was, at this time, the one area of medicine in which aspiring practitioners travelled to, rather than from, the United States, for specialist training, op. cit., note 3 above, p. 219.

${ }^{46} \mathrm{H}$ Chapman, 'Orthodontics-fifty years in retrospect', Trans. Br. Soc. Study Orthod., 1954, 40: $100-16$.
}

\footnotetext{
${ }^{47}$ B W Weinberger, 'Dr Edward Hartley Angle-his influence on orthodontics', Amer. J. Orthod., 1950, 36: 559-607.

${ }^{48}$ Chapman, op. cit., note 46 above, p. 112.

${ }^{49}$ B W Weinberger, 'The Angle School of Orthodontia', Amer. J. Orthod., 1949, 33: 298-308. But see also note 31 above.

${ }^{50}$ Taylor, op. cit., note 2 above, p. 80 . Visick would have been president but for ill-health.

${ }^{51}$ E H Angle, 'Orthodontia as a speciality', Dental Cosmos, 1902, 44: 905-10.
} 


\section{The Emergence of Orthodontics as a Specialty in Britain}

service, as he articulated it, was that the aim of treatment had become more ambitious. Its goal was now the establishment of "normal occlusion". 52 The objective was to place all the teeth in their correct relation, not only to their immediate neighbours, but also to their antagonists in the opposite jaw, and in a harmonious relation to the whole face. There was intense debate among orthodontists, in America and elsewhere, as to whether or not this ideal could be achieved in all patients and, if so, how. ${ }^{53}$ But the fact that this debate took place demonstrates the rising technical and aesthetic aspirations of practitioners of orthodontics.

Angle's bold assertion that orthodontics should be divorced from dentistry met with little support in Britain. An editorial in the British Dental Journal of 1902 stated:

Where the specialization of specialities may lead can hardly be foreseen, and we even await the prophesised eminent rhinologist devoted to the left nostril. That dental speciality admits of much division of labour without detriment is unquestionable, but the swing of the pendulum may well be too far. It appears that the orthodontist has already arrived in America, and there is a Society. ${ }^{54}$

In North America, however, the trend to separate orthodontics from general practice was gathering pace.

\section{The British Society for the Study of Orthodontics}

It was from within this context of growing professional status and confidence, coupled with considerably improved technical capability, that the British Society for the Study of Orthodontics sprung. Practitioners in Britain were aware of the increasing presence of orthodontic specialists in North America, but did not seek immediately to emulate them in their advocacy of a separate specialty. There was, in any case, as an editorial in the dental journal Items of Interest noted, a difference in the interpretation of the word "specialist", between England and the USA. ${ }^{55}$ In England, a "specialist" was often a general practitioner having an interest and expertise in a particular aspect of dentistry, whereas, in the USA, the term was used to designate someone who exclusively practised in that field. The English interpretation of specialization would certainly be formative, as we shall see, of the first British specialist society.

The driving force behind the creation of the BSSO was, without doubt, George Northcroft, who was a successful London dental practitioner. ${ }^{56}$ On 15 October 1907, Northcroft wrote to a number of his fellow practitioners inviting them to attend a preliminary meeting to discuss the foundation of a society, the object of which would be the promotion of the study of orthodontia. This meeting was held on 21 October 1907, in his

\footnotetext{
${ }^{52} \mathrm{E} \mathrm{H}$ Angle, Treatment of malocclusion of the teeth, Philadelphia, SS White Dental Manufacturing Co., 1907. The term "normal occlusion" was to cause much confusion in orthodontics because it did not describe what actually occurred in nature but expressed Angle's concept of what the ideal relationship of the teeth should be. It was, in other words, a concept of the ideal rather than the normal.

${ }^{53}$ See, for example, Editorial, 'Orthodontia and specialism', Dental Cosmos, 1903, 45: 151-3; and
}

F S McKay, 'A critical contrast between the new and the old schools in orthodontics', Items of Interest, 1906, 28: 805-36.

${ }^{54}$ Editorial, Br. dent. J., 1902, 23: 642.

${ }^{55}$ Editorial, 'Specialization in dentistry, and the ethical relations of the specialist to the general practitioner (orthodontics)', Items of Interest, 1908, 30: 626-9.

${ }^{56}$ Taylor, op. cit., note 2 above, pp. 307-9. 


\section{Geoffrey Stuart Taylor and Malcolm Nicolson}

rooms at 115 Harley Street, London. ${ }^{57}$ Eleven practitioners attended, in addition to Northcroft. Nine of those practised in the West End of London, the other two being based in Wimbledon and Eastbourne, respectively. At least seven had hospital appointments. The founders of the BSSO were evidently drawn from the upper strata, in terms of their institutional, educational and social status, of the British dental profession. ${ }^{58}$ They were the heirs of the group of practitioners who had campaigned to raise the professional standing of dentistry in the second half of the nineteenth century. It was agreed to proceed with the plan of setting up a society.

An inaugural meeting was held, by general invitation, in the rooms of the Medical Society of London, on 5 December 1907, which thirty-five people attended. ${ }^{59}$ Badcock was elected president, with Northcroft, James Sim Wallace, and Montagu Hopson being vice-presidents. All four senior office-bearers held or had recently held, posts in one or other of the London hospitals. As already noted, Badcock had been, until 1905, dental surgeon and lecturer in dental surgery at Guy's Hospital. Northcroft held a similar appointment at the London Hospital Dental School, in the founding of which he had been closely involved. Sim Wallace, the author of the influential 1904 text Essay on the irregularities of the teeth, was on the staff of several London hospitals over the course of his career, while Hopson eventually became head of the Dental School at Guy's Hospital.

The social and professional background of the early leaders of the BSSO is very revealing as to the character of the society and its aims. As Weisz has pointed out, in Britain, unlike North America or the rest of Europe, specialist expertise came to be identified as the unique possession of senior hospital staff. It was to hospital consultants, and only hospital consultants, that general practitioners referred patients in need of an expert opinion. What was odd, and distinctively British about this arrangement, was that the hospital consultants espoused an ideology of gentlemanly holism and regarded themselves as medical generalists, albeit often with some degree of specific focus in their clinical interests. ${ }^{60}$ Thus, even the major beneficiaries of the process of specialization within British medicine did not present themselves as specialists per se. Such was the authority and prestige of the hospital consultant, especially those in the London teaching hospitals, that this model came to be the definitive one for specialization in Britain. As we shall see, this pattern of specialist interest within an ostensibly generalist framework can be readily identified within the agenda of the BSSO.

In his address to the inaugural meeting, Badcock, as president-elect, pointed out that there was now sufficient demand for a society, "where members could consult and advise each other upon the problems of the already large but increasingly important branch of dental surgery, orthodontia". He felt that, "the proposed name for the society should

\footnotetext{
${ }^{57}$ Leighton, op. cit., note 5 above, p. 425.

${ }^{58}$ The first five presidents of the BSSO were all Harley Street or Wimpole Street practitioners. Three of them were medically qualified and a fourth (Northcroft) held an American DDS as well as the LDS, Taylor, op. cit., note 2 above, pp. 304-12.

${ }^{59}$ Editorial, 'Reports of societies: the BSSO', Br. dent. J., 1907, 28: 1339-40.
}

\footnotetext{
${ }^{60}$ For a full characterization of the ethos of elite London medicine, in the major teaching hospitals and around Harley Street, at the turn of the century, see C Lawrence, 'Incommunicable knowledge: science, technology and the clinical art in Britain, 1850-1914', J. Contemp. Hist., 1985, 2: 502-20; also C Lawrence and $\mathrm{G}$ Weisz, Greater than the parts: holism in biomedicine, 1920-1950, New York and Oxford, Oxford University Press, 1998.
} 


\section{The Emergence of Orthodontics as a Specialty in Britain}

indicate that it was not the intention to create a group of specialists, practising orthodontia, but to provide an opportunity when everybody who was interested in both theory and practice could meet for mutual benefit", 61

The rules of the new society were closely modelled upon those of the existing Odontological Section of the Royal Society of Medicine, which were intended to ensure that the organization was non-political and disengaged from controversy. ${ }^{62}$ One feature of the rulebook, very revealing of the society's self-image, was that members were to be prohibited from holding any commercial patents relating to dentistry. There was also an injunction against secret remedies, which were regarded as the staple of the "quack" specialist. ${ }^{63}$ One speaker at the inaugural meeting thought the prohibition against patents would have an inhibiting effect upon the future development of dental technology. Nevertheless, the gentlemanly ethos of the upper strata of London medicine, with its pronounced antipathy to trade, prevailed and the rule was confirmed. This was again in marked contrast to American practice, where several orthodontists had taken out patents on technical innovations.

The first full meeting of the BSSO took place in January 1908. As president, Badcock presented the first official paper. He chose, as his topic, the objectives of the new Society and his views are very indicative of the state of orthodontics in Britain at this time:

We are a body of men united by a common bond, interest in orthodontia ... a subject which deserves to occupy, and will occupy, a much more prominent place in the profession of general dentistry than it has done in the past. We arrogate to ourselves no special knowledge or particular skill. Any one may belong to us, whether he practise dentistry or not, if only he be interested in the problems that interest us. ${ }^{64}$

This is a very broad and inclusive remit for a special interest dental or medical society, and is quite different in character from the nearest North American equivalent. It is clear that, in offering membership to all with an interest in orthodontics, regardless of occupational status, the BSSO did not constitute itself, at least primarily, as an organization to advance the professional interests of orthodontists. Rather, the Society defined its mission as the more disinterested one of encouraging the advancement of knowledge in the field. Again there are resonances here with the constitution of the RSM. As Innes Williams has recently argued, while the RSM represented the acceptance of a degree of specialization within British medicine, in presenting itself as a purely learned society, it effectively recognized specialties as categories of knowledge rather than divisions of practice. ${ }^{65}$ While the BSSO sought to encourage the improvement of corrective technique as well as the scientific understanding of normal and irregular dentition, the similarity of its aims with those of the RSM is noteworthy. ${ }^{66}$ To some extent, as Innes Williams notes, this emphasis was chosen to avoid engagement in issues relating to competition in the medical

${ }^{61}$ J H Badcock, 'Presidential address: The study of orthodontia', Trans. Br. Soc. Study Orthod., 1908, 1: 1-5. J H Badcock had both medical and dental qualifications, from Charing Cross Hospital and the London School of Dental Surgery respectively. He spent most of his career in Harley Street.

${ }^{62}$ Forbes, op. cit., note 14 above, p. 172.
${ }^{63}$ Taylor, op. cit., note 2 above, p. 223.

${ }^{64}$ Badcock, op. cit., note 61 above, p. 1.

${ }^{65}$ Williams, op. cit., note 30 above; see also Weisz, op. cit. note 3 above, p. 41.

${ }^{66}$ Weisz, op. cit., note 3 above, p. xxi, makes what is for him an important analytical distinction between specialization based on knowledge and that based on skill. This distinction would not, 


\section{Geoffrey Stuart Taylor and Malcolm Nicolson}

marketplace. Nevertheless, it is also true, as the quotation from Badcock indicates, that the founding figures of the BSSO evidently believed that development of the scientific and academic content of the subject would assist orthodontics in achieving "a much more prominent place" within dentistry as a whole.

Badcock acknowledged that anxieties had been expressed that the creation of a new society, devoted solely to one particular branch of dentistry, could be divisive within the dental profession. But he regarded this apprehension as being groundless. He was not, however, in principle against specialization in the North American sense. He foresaw that eventually, at least in the larger centres of population, only full-time specialists might provide an orthodontic service. In his judgement, this development would be beneficial. Interestingly, Badcock compared the advantages to be gained from orthodontic specialization to those that would accrue from the administration of anaesthetics by specialist anaesthetists, as against administration by general practitioners with an interest in anaesthesia, which, he stated, was the usual practice at the time. ${ }^{67}$ In other words, Badcock was prepared, at least partially, to repudiate the view, widespread still among medical practitioners in Britain, that full-time specialization was necessarily to be deplored.

As mentioned earlier, in the first decades of the twentieth century, North American orthodontics was riven by acrimonious controversy, relating to both the cause and the treatment of malocclusion. The Society's founders were very anxious that these divisions should not be replicated within the BSSO. With characteristic moderation, Badcock emphasized the Council's desire to include representatives from all schools of thought. Another of the early presidents, Harry Baldwin, described the Society as a "model of seductive humility" and was evidently proud that the Society enjoyed a harmonious relationship with the generalist British Dental Association. ${ }^{68}$

Some of the controversy which disturbed North American orthodontics centred on Angle's rigid insistence that it was bad practice to extract healthy teeth to facilitate tooth re-alignment. This tenet became the governing principle of those full-time American orthodontists who practised the Angle method. Badcock argued, however, that many potential orthodontic patients could not afford either the money or time for prolonged and sophisticated treatment, and for those patients extraction was a necessary part of successful management. This was, effectively, a recognition of the differences between the British and American circumstances of orthodontic practice. Several of Badcock's audience would have held appointments in voluntary hospitals where they would provide economical treatment for charitable patients. Moreover, British orthodontists knew that if they wished to expand the range of patients that they treated, it was necessary to make available a simplified form of treatment. ${ }^{69}$

however, seem to be necessary to understanding the development of specialization in orthodontics.

${ }^{67}$ For an account of the position of the general practitioner/specialist in anaesthesia, see G Weisz, 'Medical directories and medical specialization in France, Britain and the United States', Bull. Hist. Med., 1997, 71: 23-68.

${ }^{68} \mathrm{H}$ Baldwin, 'Presidential address', Trans. $\mathrm{Br}$. Soc. Study Orthod., 1912, 5: 2-4.

${ }^{69} \mathrm{~F}$ Mellersh, 'President's address', Trans. Br. Soc. Study Orthod., 1915, 8: 11-13. 


\section{The Emergence of Orthodontics as a Specialty in Britain}

On the other hand, Badcock also deplored those orthodontists who viewed treatment purely in empirical, mechanical terms. In his view, the realignment of the teeth could be successful, in the long term, only if it was based upon sound biological principles. He admitted that the profession was still woefully ignorant in the fields of aetiology, pathology and prophylaxis. Again the stated purpose of the Society was to be a disinterested forum-a vehicle for the advancement, not merely of technique, but of science.

Badcock concluded by outlining the Council's plans for furthering the aims of the Society. Future meetings would consist of the reading and discussion of papers, casual communications and clinical evenings of a practical nature. ${ }^{70}$ A library and museum would be created, "investigation committees", comprising small groups of members, would be set up to look at selected topics. He mentioned normal arch determination, classification and orthodontic terminology as possible topics for the attention of these investigating committees.

Thus, we can discern, in its first presidential address, some of the distinctive characteristics of the British Society for the Study of Orthodontics. Its constitution emulated the gentlemanly ethos of London patrician medicine, with its disdain for trade and its antipathy towards factional enthusiasm. It saw the future progress of orthodontics as being best achieved through the liberal ideals of the advancement of knowledge and the improvement of education, rather than by the pursuit of specialization and professional organization. Many of its founders had links with the London teaching hospitals and/ or with socially exclusive private practice, of the Harley Street variety. While not necessarily or wholly antipathetic to specialist practice, most of the leading members identified themselves, as we shall see, as generalists with a special interest in orthodontics, rather than as specialist practitioners, per se. The BSSO was, in other words, a distinctively British specialist body.

The BSSO met seven or eight times a year. Each meeting usually consisted of the presentation of a long paper and several shorter papers or demonstrations. Sometimes papers shared a related theme. Approximately twenty papers or demonstrations were subsequently published in the Society's annual Transactions. Every year its president addressed the Society, and these addresses, also published in the Transactions, provide a valuable record of the opinions of the leading figures in British orthodontics, from 1907 onwards. $^{71}$

It is evident from the Transactions that not all the members of the Society were content with the first president's relatively relaxed attitude to the prospect of full-time practice. In 1910, Sim Wallace was elected president. ${ }^{72}$ His presidential address reaffirmed his commitment to generalism, in terms with which many of his colleagues in metropolitan medicine and dentistry would have been very familiar. The danger of specialization was, he argued, that it confined its practitioners "to a narrow rut, distorting the sense of

\footnotetext{
${ }^{70}$ Badcock, op. cit., note 61 above, p. 1; Taylor, op. cit., note 2 above, p. 98.

${ }^{71}$ Taylor, op. cit., note 2 above, p. 94.

${ }^{72}$ James Sim Wallace graduated in medicine from Glasgow University before moving to London to
}

qualify in dentistry. He also obtained the Glasgow MD and DSc, becoming the first recipient of the latter qualification for dental research. 


\section{Geoffrey Stuart Taylor and Malcolm Nicolson}

proportion and limiting the large and liberal outlook, which should be characteristic of a learned profession". Such restriction of vision was stigmatized as "the curse of specialism". ${ }^{73}$ Sim Wallace emphasized that the BSSO had been set up to serve the high ideal of the study of orthodontics and not merely to improve its practice or even its teaching. The implication was clear; full-time specialization, by depriving those interested in orthodontics of a broad intellectual outlook, would hinder rather than advance the development of their subject.

But those presidents who concerned themselves with the quality of the British teaching of orthodontics frequently tended to a different view. This was particularly true of those who contrasted the situation in Britain with that in North America, to whose specialist institutions, as we have seen, many British prospective practitioners travelled to receive postgraduate training. For instance, in 1915, Frank Bouquet Bull, a leading member of the Society and a future president, firmly expressed his low opinion of the quality of the teaching of orthodontics in Britain. ${ }^{74} \mathrm{He}$ attributed this deficiency to the fact that both lectures and clinical instruction in orthodontics were combined with dental surgery. With very few exceptions, the actual teaching was still carried out by generalists rather than specialist orthodontists. Bull pointed out that the prolonged nature of orthodontic treatment made it difficult to incorporate within the standard curricula of general dentistry. Most dental students undertook just over two years of clinical instruction but this was rarely long enough to follow a single orthodontic case to conclusion. Bull also believed that, until students had gained some basic knowledge of orthodontics, they could not fully appreciate its value. Thus many would-be practitioners, who might otherwise have been attracted to orthodontics, chose to remain with restorative dentistry.

Bull recommended that orthodontic instruction should be separated from that of general dental surgery, and that it should be postponed until the second year of clinical studies. By this stage students would be better prepared to benefit from the teaching. In the second year, a period of three months should be set aside exclusively for orthodontics. Bull applauded the fact that the London Dental Hospital and the Birmingham Dental School had already implemented such a system. He suggested that independent Orthodontic Departments be created, each to be under the direction of someone with a particular interest in orthodontics, preferably assisted by a demonstrator and a specialist orthodontic house surgeon. This, he believed, would enable both patient management to be more effective, and the standard of teaching to be improved.

Bull was not the only eminent British orthodontist concerned about these matters. In 1916, Bertram B Samuel gave a short paper entitled 'Suggestions for the formation of a London orthodontic centre'. ${ }^{75}$ As he saw it, orthodontics in England had two serious

\footnotetext{
${ }^{73}$ J Sim Wallace, 'Presidential address: Specialism in relation to the study of orthodontics', Trans. Br. Soc. Study Orthod., 1910, 3: 2-6; Cantor, op. cit., note 17 above, p. 136.

${ }^{74} \mathrm{~F}$ B Bull, 'The teaching of orthodontics', Trans. Br. Soc. Study Orthod., 1915, 8: 26-35. Bull graduated in both dentistry and medicine at Guy's Hospital and became Head of the Children's Department of the Dental School.
} 


\section{The Emergence of Orthodontics as a Specialty in Britain}

deficiencies, the dearth of treatment facilities for less well-off children and the absence of opportunities for postgraduate training. The establishment of a dedicated clinical centre in London would meet both needs. Samuel proposed the Forsyth Institute in Boston as a model for orthodontic education in Britain.

Bull's and Samuel's papers were both delivered in the second year of the First World War. The war imposed a hiatus on British dentistry as a whole and upon the activities and development of the British Society for the Study of Orthodontics in particular. Many dentists were heavily involved in the war effort, dealing with maxillo-facial injuries. Orthodontic work was substantially curtailed. Even after peace returned, orthodontic treatment remained available to only a very small section of the population. The vast majority of the work was still carried out by dentists who also practised other branches of dental surgery. Even the teachers in the orthodontic departments of the dental schools were not necessarily orthodontic specialists in the North American sense, although they would certainly have had considerable expertise in the subject. However, the British Isles had, as we have already noted, begun to acquire their first full-time orthodontists. The case for and against specialization would continue to be discussed at the meetings of the Society for many years to come. But when J L Payne gave his presidential address in 1921 he seems to have considered that the principle of specialization had become accepted. ${ }^{76} \mathrm{~S}$ Spokes, president in the following year, judged that the development of orthodontics as a specialty had not been detrimental to the general dental practitioner but had benefited the profession as a whole. ${ }^{77}$

Throughout the 1920s and 1930s, the technical repertoire of the orthodontist continued to improve and expand. A notable advance was the introduction of stainless steel, which was employed in the construction of bands, arches and springs. Stainless steel was much cheaper and more clinically effective than the previous metal of choice, gold. However, considerably more skill was required to work the new material, stainless steel being difficult to weld. Friel was a major pioneer for the introduction of stainless steel, and several other British orthodontists contributed to the realization of its clinical potential. ${ }^{78}$ A further important innovation was the adoption, with modifications, by British orthodontists of Angle's pin and tube method of effecting tooth movement. This new procedure, together with other similar techniques, again enhanced clinical effectiveness, while demanding great precision in its construction and manipulation.

In 1921, unregistered dental practice was finally made illegal in Britain. There was, however, a considerable shortage of dentists, ${ }^{79}$ and therefore little economic incentive for the ordinary dentist to diversify his practice ${ }^{80}$ From the 1920 s onwards, for a variety of

\footnotetext{
${ }^{76}$ J L Payne, 'Presidential address: Orthodontics', Trans. Br. Soc. Study Orthod., 1921, 10: 5-9.

${ }^{77} \mathrm{~S}$ Spokes, 'President's address', Trans. Br. Soc. Study Orthod., 1922, 11: 5-7.

${ }^{78} \mathrm{~S}$ Friel, 'The practical application of stainless steel in the construction of fixed orthodontic appliances', Trans. Br. Soc.
}

Study Orthod., 1933, 21: 31-55. Related papers by Frank B Bull and Ernest R Rix, Harold Watkin, Norman Gray and Robert Cutler are discussed in Taylor, op. cit., note 2 above, p. 263.

${ }^{79}$ Forbes, op. cit., note 14 above, pp. 179-80.

${ }^{80}$ At this time, the overwhelming majority of British dentists were male. 
reasons - awareness of lack of knowledge and equipment, legal considerations, ready availability of other remunerative work-many general practitioners were unwilling to undertake orthodontic work. ${ }^{81}$ And those who did perform such work tended to employ the cheaper and easier techniques. They were inclined, for instance, to favour removable appliances rather than the fixed ones, which were generally more precise and powerful but required more skill to fit and took up more chair time. Thus, the gap between the standards of orthodontic work carried out by the general practitioner and that undertaken by the full-time specialist, or taught within the orthodontic departments of the dental hospitals, continued to widen. British orthodontists, meanwhile, looked across the Atlantic and saw that, if the standard of the teaching of orthodontics in Britain was to match its American counterpart, then more specialized facilities and specialist teachers were required. Between the wars, calls for the setting up of a dedicated postgraduate centre for orthodontics in London were regularly repeated. It was even suggested that it could be run under the auspices of the BSSO. ${ }^{82}$

Nothing came of these plans. However, in 1931, the Eastman Dental Clinic opened in London. This included a separate orthodontic department, which provided both affordable treatment and postgraduate orthodontic training. ${ }^{83}$ After the Second World War, the Eastman was incorporated into the British Postgraduate Medical Federation. ${ }^{84}$ Under the leadership of Clifford Ballard, its orthodontic department came to play a very important role in the further development of the subject in Britain. ${ }^{85}$

The establishment of the National Health Service in 1948 created the conditions for a great expansion in the provision of orthodontic care in Britain. The principle of a statefunded health care system seems to have been enthusiastically endorsed by the leadership of the BSSO. In 1942, the Society set up a committee to examine the implications of the Beveridge Report for orthodontics. Faced with the prospect of a need-driven health service, free at the point of delivery and presumably including orthodontics in its comprehensive provision, the committee considered what sort of orthodontic care could be delivered to the general population, and by whom. In 1945, giving the first presidential address for six years, tellingly titled 'Our opportunity', Norman Gray welcomed the forthcoming peacetime expansion of health care as providing the prospect of raising the standards of British orthodontics and increasing the numbers of its practitioners. ${ }^{86}$ Noting that his predecessors had expressed differing opinions on the subject, Gray affirmed his belief that the time for specialization had finally arrived. He envisaged that the demand for orthodontic treatment would greatly increase once the financial obstacles that had excluded poorer children were substantially removed. The challenge was to train sufficient numbers of specialists to meet the orthodontic needs of the population.

\footnotetext{
${ }^{81}$ Taylor, op. cit., note 2 above, p. 120.

${ }^{82}$ G F Cale-Matthews, 'British Society for the Study of Orthodontics', Trans. Br. Soc. Study Orthod., 1926, 15: 2-9.

${ }^{83} \mathrm{C}$ I Endicott, 'The work of the orthodontic department of the Eastman Dental Clinic', Trans. Br. Soc. Study Orthod., 1938, 27: 68-95.
}

\footnotetext{
${ }^{84}$ For the history and significance of the British Postgraduate Medical Federation, see F Fraser, The British Postgraduate Medical Federation: the first fifteen years, London, Athlone, 1967. p. 331.

${ }^{85}$ Taylor, op. cit., note 2 above,

${ }^{86} \mathrm{~N}$ Gray, 'Our opportunity: presidential address', Trans. Br. Soc, Study Orthod., 1944-45, 31: 22-7.
} 


\section{The Emergence of Orthodontics as a Specialty in Britain}

In the same year, Friel also urged his fellow orthodontists to embrace the ideal of fulltime specialization as the only way, as he saw it, to raise British orthodontic standards to the level that had been achieved in the United States. ${ }^{87}$ Friel deprecated the fact that much treatment in Britain was still undertaken by, as he put it, "skilled amateurs" and argued that attempts to expand the provision of treatment without the introduction of adequate postgraduate education would simply prolong this unwelcome circumstance. His choice of terms is an indication of how far the discourse surrounding specialization in British dentistry had changed. Whereas previously the integration of orthodontics within the general practice of dentistry had been praised as conducive to a "sense of proportion" and a "large and liberal outlook", it was now stigmatized as "amateurism". The "curse of specialism" had evidently been lifted. ${ }^{88}$

The administrative structure that was chosen for the NHS imposed a rigid division between hospital doctors and community-based general practitioners, an arrangement which was very conducive to the establishment of specialties. Gradually, many more consultants were recruited in virtually every branch of medicine and dentistry, including orthodontics. ${ }^{89}$ At the same time, the universities became more involved in orthodontic education. The first reader in orthodontics, Corisande Smyth, was appointed in 1951 at the Royal Dental Hospital School and the first professor, Clifford Ballard, at the Institute of Dental Surgery, University of London, in $1956 .{ }^{90}$ Other educational innovations were made. In 1949, the Faculty of Physicians and Surgeons of Glasgow awarded their first Diploma of Dental Orthopaedics. The Royal College of Surgeons of England followed suit in 1954.

By the mid-1950s, it was apparent, however, that the impact of the setting-up of the NHS on the process of specialization in orthodontics had been, to an extent, paradoxical. Many more specialists were being trained but, owing to demand for treatment vastly outstripping supply, more orthodontic work was being undertaken by general practitioners, often using limited means of treatment and under great time pressure. The membership of the BSSO continued to include a substantial number of general practitioners, reflecting the dual avenues of service provision.

The changes that the founding of the NHS had set in train did not come fully into effect until the 1960s, when substantial numbers of orthodontic specialists were appointed, either as consultants in dental hospitals or with regional hospital boards. Oddly enough, however, this expansion of the specialty was to prove fatal for the BSSO. As noted above, its founders had conceived the BSSO rather as a learned society for the advancement of orthodontics than as a professional body to speak for orthodontists. This direction was taken partly to avoid the factionalism that had marked orthodontic societies in North America. However, the Society's constitution was interpreted, by successive meetings of its Council, as precluding its involvement in any discussion or consultation remotely political, even when

\footnotetext{
${ }^{87} \mathrm{~S}$ Friel, 'Postgraduate school for the training of orthodontists', Brit. dent. J., 1945, 79: $157-60$.

${ }^{88}$ Wallace, op. cit., note 73 above, p. 2.

${ }^{89} \mathrm{~F}$ Honigsbaum, The division in British medicine: a history of the separation of general practice from
}

hospital care, 1911-1968, London, Kogan Page, 1979, pp. 301-18.

${ }^{90}$ Smith and Cottell, op. cit., note 25 above, p. 114; Anon., 'Obituary, Clifford F Ballard', Brit. dent. J., 1998, 184: 310. Friel had been appointed to a chair in orthodontics in Trinity College, Dublin, in 1941. 


\section{Geoffrey Stuart Taylor and Malcolm Nicolson}

orthodontic service provision was involved. In 1919 the Parliamentary Health Committee invited the BSSO to send a report on its activities. The Secretary was instructed to decline, and reply that their activities "did not extend to political affairs". When, in 1920, the Federation of Medical and Allied Societies invited the BSSO to affiliate, the Secretary replied that it was "not empowered by its Bye-laws to join". 91

This fastidiousness also prevented the Society from exercising its full influence during the planning and implementation of the NHS. ${ }^{92}$ It was initially reluctant, for instance, to become involved in the consideration of specialist titles within the Service. The BSSO also declined to give any advice to the British Dental Association regarding charges for orthodontic appliances. In 1962, the Society was invited to submit evidence to the Standing Dental Advisory Committee on hospital dental services. It again refused, expressing a wish not "to become involved in administrative problems". This decision was eventually reversed, under pressure from the membership of the Society, but the damage had been done. Widespread dissatisfaction with the aloofness of the BSSO from matters relating to professional interests, particularly amongst members carrying out a significant amount of orthodontic treatment in practice as opposed to the hospital service, led to the formation of the British Association of Orthodontists in 1965. The BSSO lost a number of members to the new body, whose membership was restricted to those who were full-time, or nearly full-time, orthodontic practitioners. The British Association sought actively to articulate its members' points of view in the political arena. Eventually, in 1994, the BSSO lost its separate identity, merging with a number of other orthodontic groups to form the British Orthodontic Society.

\section{Conclusion}

For many years, the British Society for the Study of Orthodontics reflected the values of the metropolitan dental elite. As such, it embodied the patrician and liberal values of a gentlemanly generalism and the disinterested pursuit of knowledge which had characterized much of the discourse of the upper strata of the medical and dental professions in the last decades of the nineteenth century. By 1907, when the Society was formed, the dominance of the ideology of generalism was waning in medicine and the BSSO's relatively relaxed attitude to specialization reflected this. But more conservative voices defending the sanctity of generalism were often heard at the Society's early meetings. The Society would long bear the imprint of the circumstances of its foundation. It never became merely or largely a professional body. While it was, of course, necessary for orthodontists to establish themselves in the market for patients, the BSSO sought to advance the interests of their subject indirectly by raising its

${ }^{91}$ Taylor, op. cit., note 2 above, p. 221.

\footnotetext{
${ }^{92}$ These aspects of the Society's policies are described in detail in Taylor, op. cit., note 2 above, pp. 216-23.
} 


\section{The Emergence of Orthodontics as a Specialty in Britain}

public profile and by encouraging the development of its scientific and technical knowledge base.

The prevalence of generalist attitudes among many of the members of the BSSO notwithstanding, by the 1960s orthodontics had become, de facto, a fully-fledged specialty within the National Health Service. To what extent, one might ask in the light of the secondary literature on medical specialization, was this inevitable? The structure of the NHS encouraged the expansion of the consultant grade within dentistry and the trend towards specialization in orthodontics was certainly accelerated by this circumstance. But probably even more important was the paradigm offered by the development of orthodontics in America. From the early twentieth century onward, British orthodontists looked, and often travelled, across the Atlantic. They saw that their American counterparts had achieved specialist status and had secured a remunerative position in the dental marketplace. What was more, American orthodontists were evidently in advance of their British counterparts in terms of technique and sophistication of treatment. This is not to say that British orthodontists always slavishly followed the exemplars offered from the United States. The Transactions of the British Society for the Study of Orthodontics provide many instances of speakers deprecating North American methods of treatment as "mechanical" when compared with the more "biological" approach preferred in Britain. ${ }^{93}$ American orthodontists were also held to focus on aesthetic considerations, whereas the emphasis in Britain was strongly on function. ${ }^{94}$ But, nevertheless, with American orthodontics so thoroughly specialized, it was unlikely that British practice could remain generalist indefinitely. Our paper has sought to highlight the importance of cultural context in the process of specialization, and the specialization of British orthodontics might be said to be as inevitable, or otherwise, as any other instance of cultural imperialism.

We have also argued that the development of a technology specific to the correction of irregular dentition was a factor in the growth of a distinctive professional identity among orthodontists. The development and transmission of a unique material culture is, in other words, an enabling condition in the process of specialization. Similar points have been made, albeit less explicitly, by historians studying the development of the specialties of gynaecological surgery and, to cite a classic non-medical example, radio-astronomy. ${ }^{95}$

As noted in the introduction, many commentators have pointed to the role of economic competition in the origins of specialization. The specialist, it is argued, differentiates from the generalist in order to offer the patient a distinctive product and thus acquire some of the generalist's market share. But it is difficult to discern such a process in the history of British orthodontics. One might even suggest that, on this occasion, the specialist took over aspects of practice that the overworked and hard-pressed general dentist did not particularly want

\footnotetext{
${ }^{93}$ Taylor, op. cit., note 2 above, quotes many examples ranging from Badcock and Rushton in the early meetings of the Society until Ballard and John D Hovell in the 1960s.

${ }^{94}$ Taylor, op. cit., note 2 above, p. 201.
}

\footnotetext{
${ }^{95}$ O Moscucci, The science of woman: gynaecology and gender in England, 1800-1929, Cambridge University Press, 1990; D O Edge and M J Mulkay, Astronomy transformed: the emergence of radio astronomy in Britain, New York and London, Wiley, 1976.
} 
Geoffrey Stuart Taylor and Malcolm Nicolson

to keep. This could be seen as another area in which the history of British orthodontics differs from that of the United States.

The history of the British Society for the Study of Orthodontics could be said to show that the process of specialization in British orthodontics arrived at an end point similar to that of the corresponding process in the United States but that it did so by a characteristically British route. 